
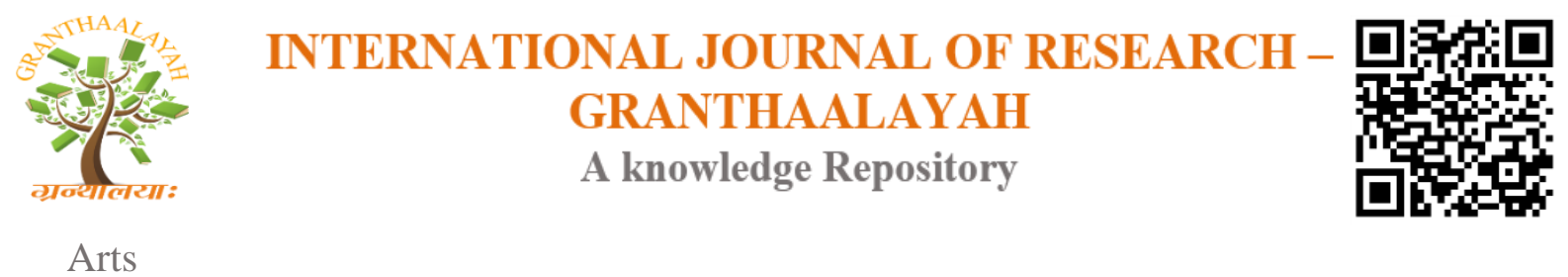

\title{
ORCHHA- THE ARCHITECTURAL HERITAGE OF MADHYA PRADESH
}

\author{
Dr Anjali Pandey ${ }^{* 1}$ \\ ${ }^{* 1}$ Association Professor \& H.O.D., Drawing \& Painting Department, Govt. M.L.B. Girls P.G. \\ Autonomous College, Bhopal, India
}

\begin{abstract}
Orchha is a historically famous site of Bundelkhand region in Niwari district of Madhya Pradesh. It has the wide collection of tremendous Imperial monuments with historic importance and natural and living heritage at National and international level. The Jahangir Mahal, Raj Mahal and Sheesh Mahal are the three sections of Orchha Palace Complex. The blend of Mughal and Bundelkhandi style of architecture is really appreciable for its harmony, intelligent engineering and magnificent building. Jahangir Mahal was built in honour of Mughal Emperor Jahangir. Orchha is also famous for the Ram Raja temple where the Bhagwan Ram is worshipped as a king. Lakshmi Narayan temple and Chaturbhuj Temple have unique Temple designs. There are 14 Chhatri or cenotaphs of the rulers of Orchha. The art, architecture, legends and the myths celebrate the glory of Orchha.
\end{abstract}

Keywords: Cultural Heritage; Bundela Dynasty; Mughal Influence Bundeli Architectural Style; Citadels; Chhatri; Dome; Arch; Courtyard.

Cite This Article: Dr Anjali Pandey. (2020). "ORCHHA- THE ARCHITECTURAL HERITAGE OF MADHYA PRADESH.” International Journal of Research - Granthaalayah, 8(4), 262-274. https://doi.org/10.29121/granthaalayah.v8.i4.2020.32.

\section{Introduction}

Orchha has a rich architectural heritage under the protection of the Department of State Archaeology. The word Orchha means 'ondche' or 'hidden. ${ }^{1}$ Natural landscapes, forest centuries, historical architecture, social, literary and religious aspects build it multidimensional.

This town is situated at the bank of Betwa River in Niwari district of Madhya Pradesh, 15 kilometers away from Jhansi of Uttar Pradesh. It was formerly the capital of Bundelkhand region. ${ }^{2}$ The town was founded in the 16th century by the Bundela chief Rudra Pratap ${ }^{3}$. He was the great Patron of art and literature. He built many temples and palaces. He identified the Orchha as a site for building of Fort.

Bundela legends are an oral depiction of collective memories. Its cultural heritage is sustained in its myths, ballads, folk and literature. 'Harbole' of Bundelkhand were the great Chhansoniaror and 
they played an important role to interpret the historical events in their ballads. These legends personify the bravery and devotion of Bundela rulers and revitalize the remembrance.

Keshav Das the Great scholar of Ritikal was born at Orchha in 1555. His ancestors were the scholars of Orchha kingdom. At the time of King Madhukar Shah and Veer Sing Dev's reign, he was associated with the Orchha Court. 'Rasik Priya' and 'Ramchandrika' are his famous compositions. Through his hagiography 'Ratan Bavani' and 'Veer Charit', we are able to see the whole scenario and historical facts of the Bundela period, through which he expressed his reverence and respect to the Bundela princes. ${ }^{4}$ Later the great ruler Bir Singh Dev 1605-1627 played an important role in patronizing the great style of art and architecture.

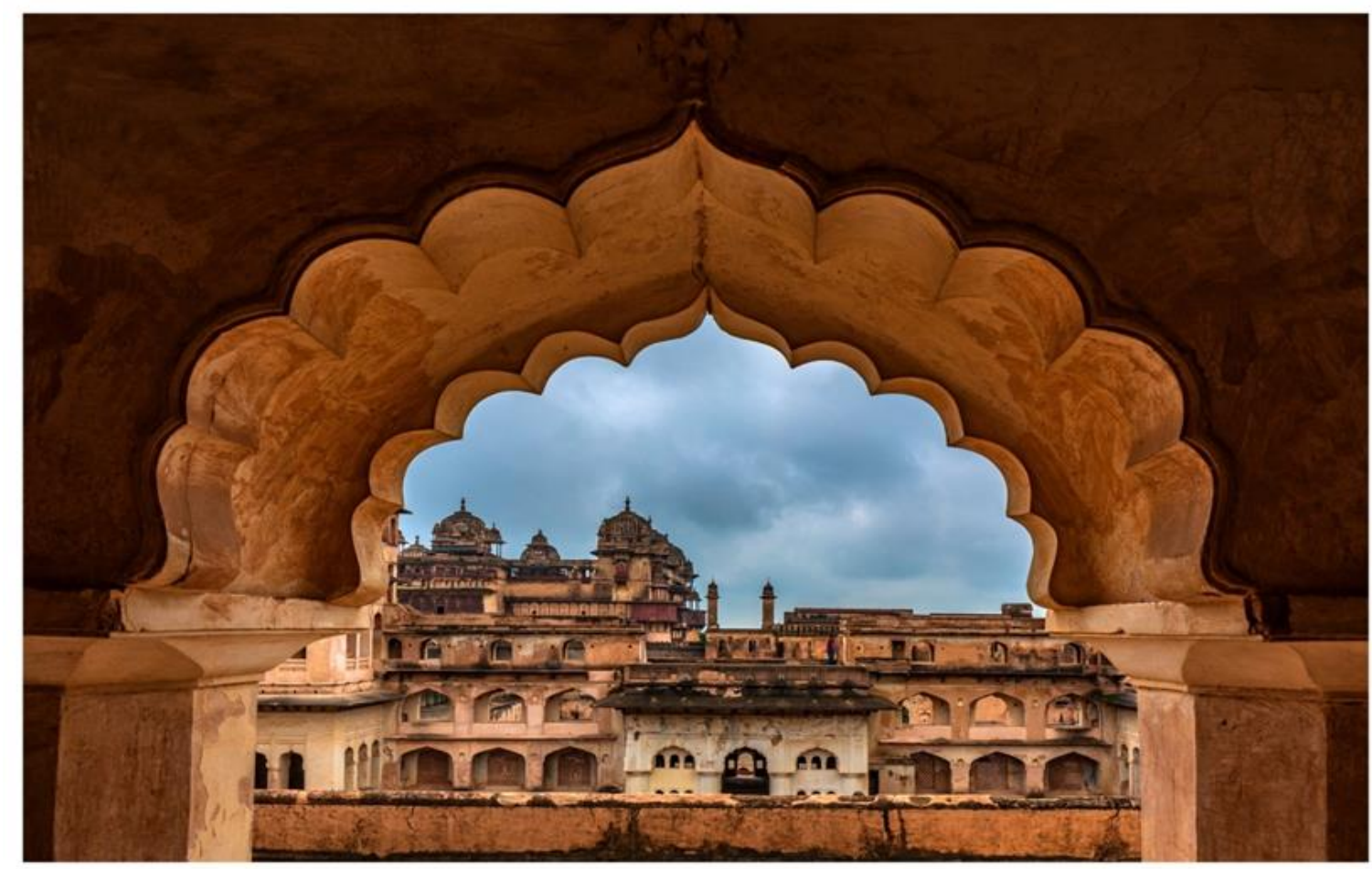

State Archaeology of Madhya Pradesh has protected 36 monuments of Orchha and 20 are in the recommendation list for protection. In the town there are some monuments, out of which some are the places of worship and others are used as government offices. The monuments built at the time of Veer Singh Dev in 16th-17th century are the perfect example of the time. Sawan Bhado Mahal, Jahangir Mahal was built at the time of Veer Singh Dev. ${ }^{5}$

Orchha has remarkable town planning, garden design, landscape temples, monuments, fortifications, murals and natural heritage. The intimate relationship between architecture and landscape are the aesthetic statements of the time. It displays the unique harmonious and form of Gardens of Mughal style Charbagh and Rajput fort gardens. The architectural design of the fort and temples are innovative and based on Mandal plans. The fort palace complex lies towards the eastern bank on an island between the river Betwa and Jamni. It has the fortified wall of 10.35 meter high with 15 rounded bastions and three main entrance gate. ${ }^{6}$ 


\section{Raj Mahal Palace}

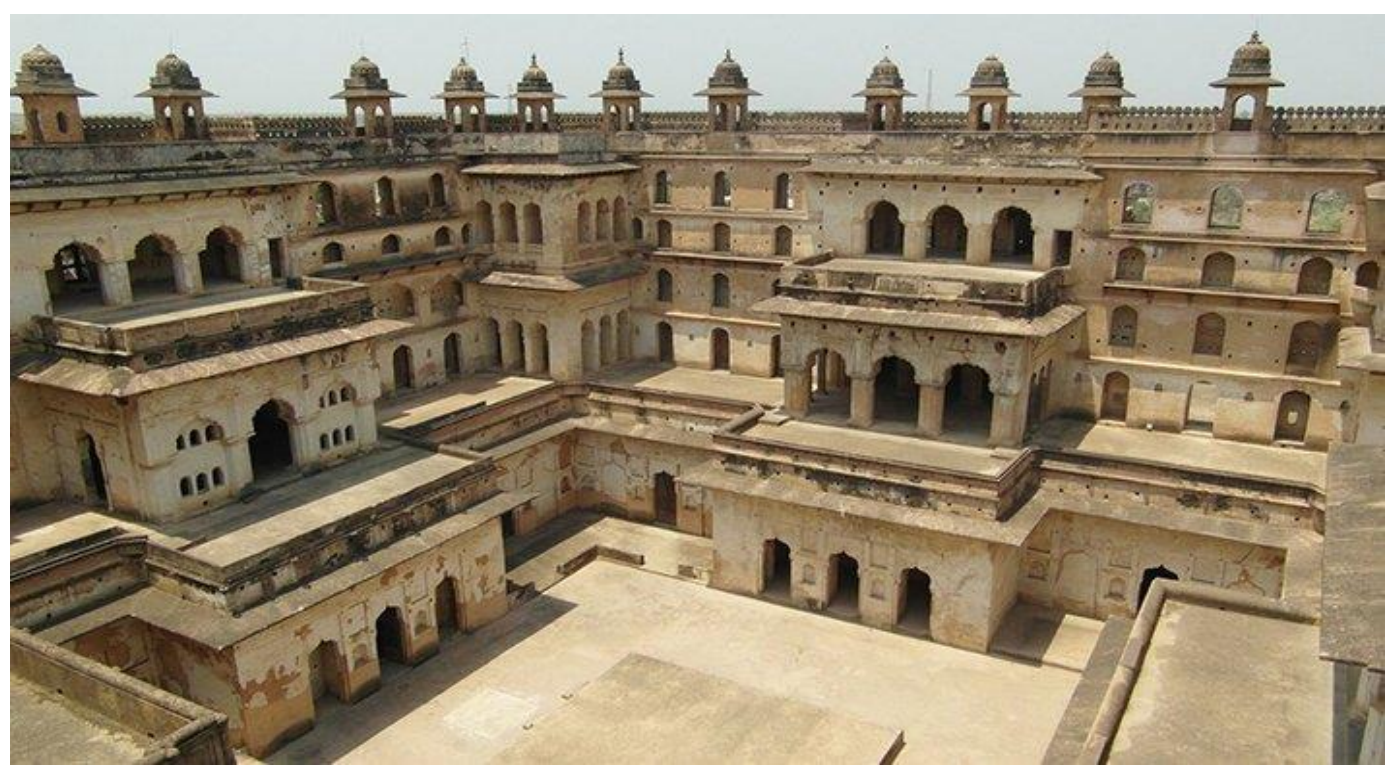

The Raj Mahal was started to be built at the time of King Rudra Pratap Singh in 1531 and in 1539 it got completed at the time of Bharti Chandra the successor of king Rudra Pratap. Some additions and alterations were made at the time of king Madhukar Shah. The exterior of the palace looks simple without any ornamentation. It is a residential palace and earliest building of the citadels which was constructed. The Palace has two wings, one side is four storey and other three sides have five storey. Deewan-e-Aam and Diwan-e-Khaas are the important one. Diwan-e-Aam is used for public meeting. It is a twenty eight pillered hall with three platforms. The utmost platform is for royal seat. The heights of the platform were used according to the rank of ministers and nobles. The entrance is the Eastern and opens in a courtyard of Diwan-e-Khaas. These courtyards were used for the everyday gathering and on the occasion of festivals and rituals. ${ }^{7}$

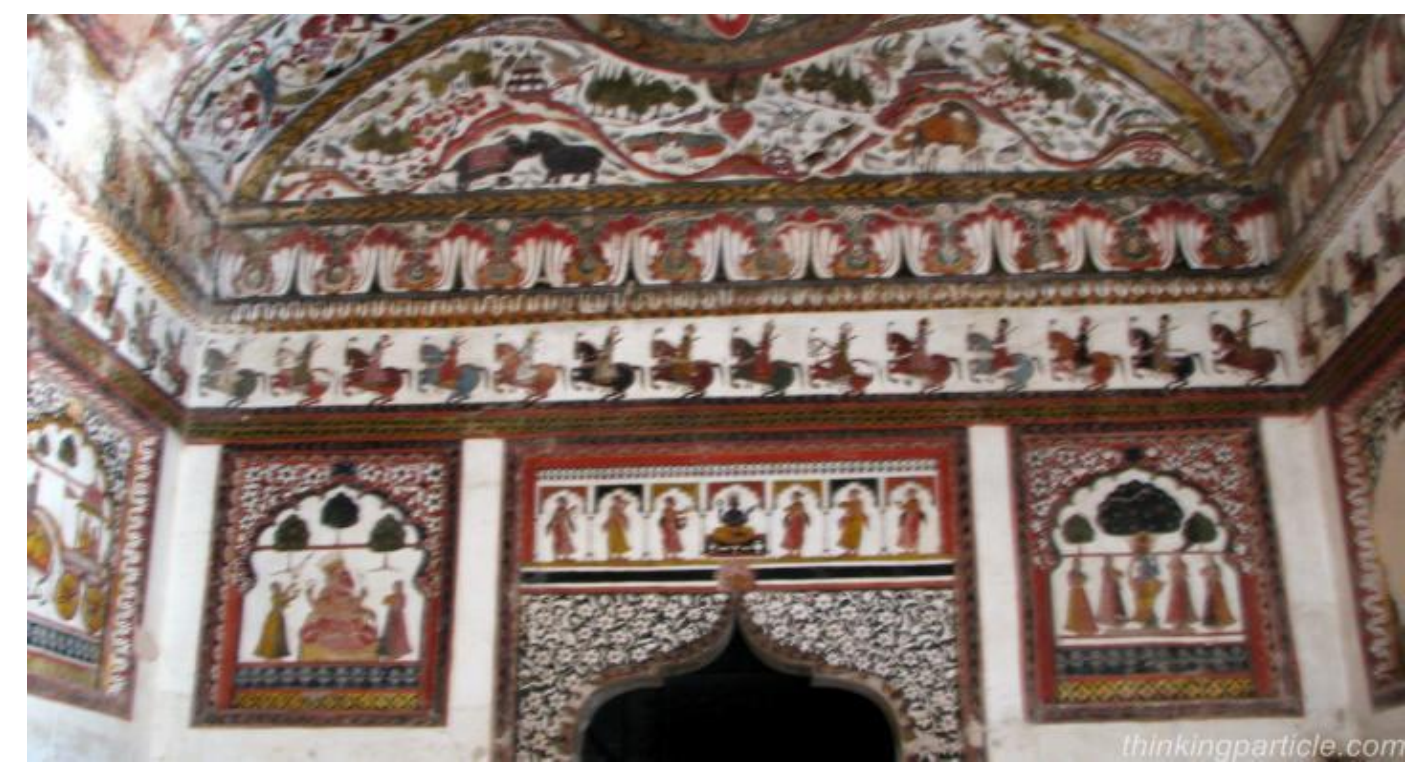




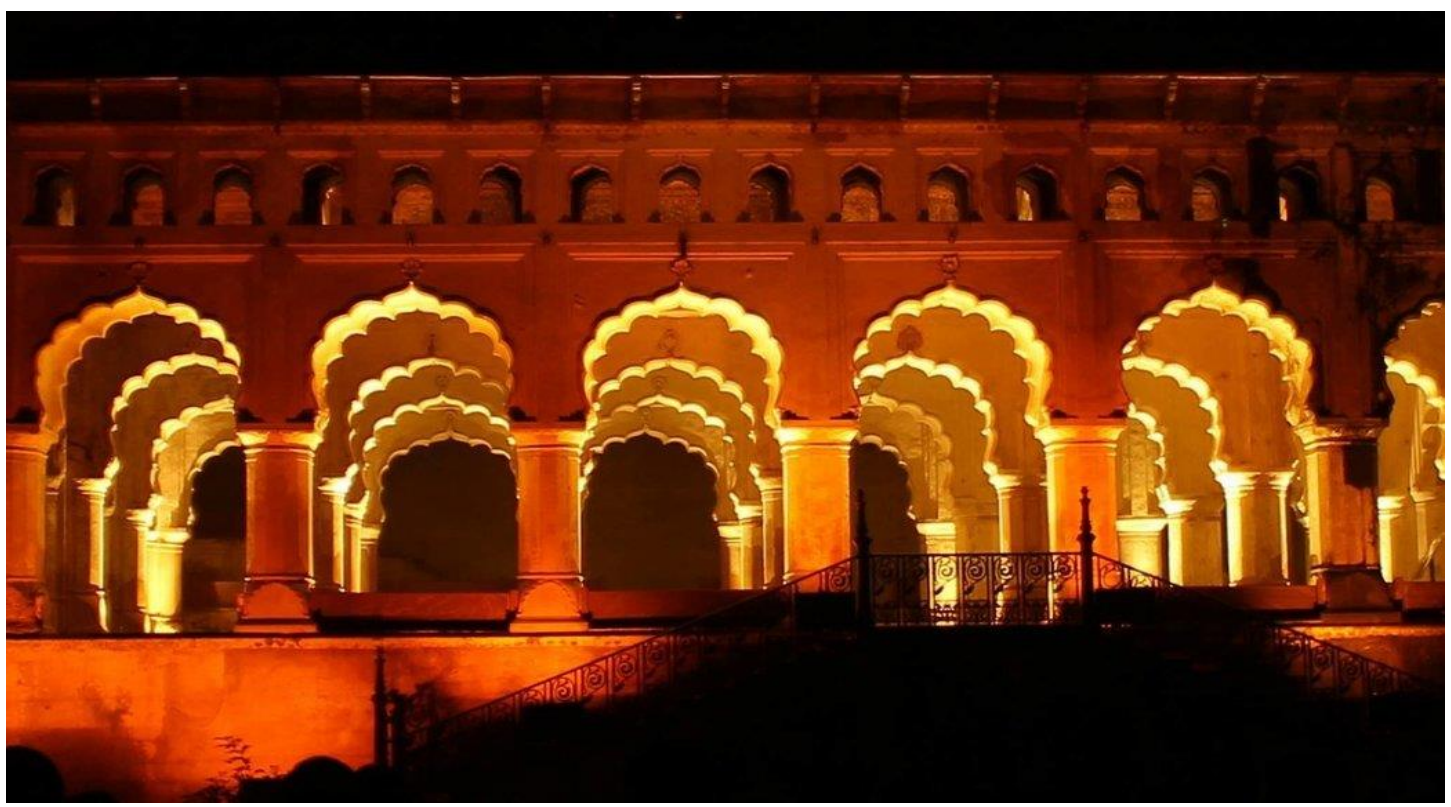

The interior of the building has a royal touch. The mural paintings have the life and deeds of Bhagwan Ram and Krishna, Dashavatar, Raag- Ragini, Nayak-nayika , hunting, amusement, folk and the other subjects are the representation of the iconic imagination of the cultural world of Bundela reign. ${ }^{8}$

\section{Jahangir Palace}

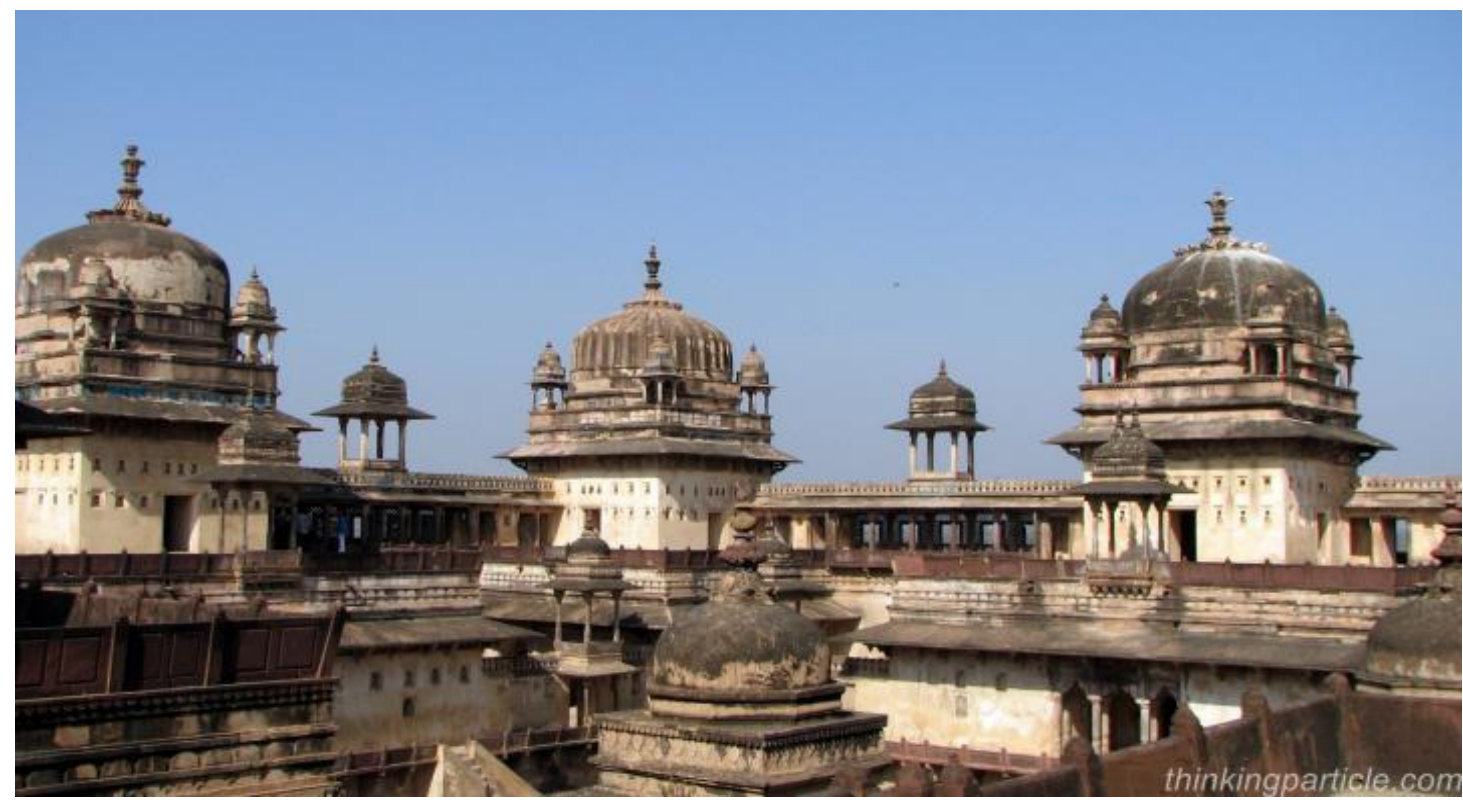

Jahangir Palace was built by the ruler Veer Singh Dev. The construction of the palace started in 1605. It is said that this palace was constructed in honour of the Mughal Emperor Jahangir who stayed here for one day. ${ }^{9}$ It is a fine example of harmonious visual language of Indo-Islamic style of monument, built with red and yellow sandstone. It is situated at the bank of Betwa River. 
Jahangir Mahal is square in plan, with four bastions at each corner with eight topped dome. ${ }^{10}$ It is a three storied palace ${ }^{11}$ with a fountain in the centre. The ceremonial Gateway of the palace is east facing in traditional and artistic grandiose. Two stone elephants guard at the entrance stairway ${ }^{12}$ with ringing bells for the announcement of the king's arrival.

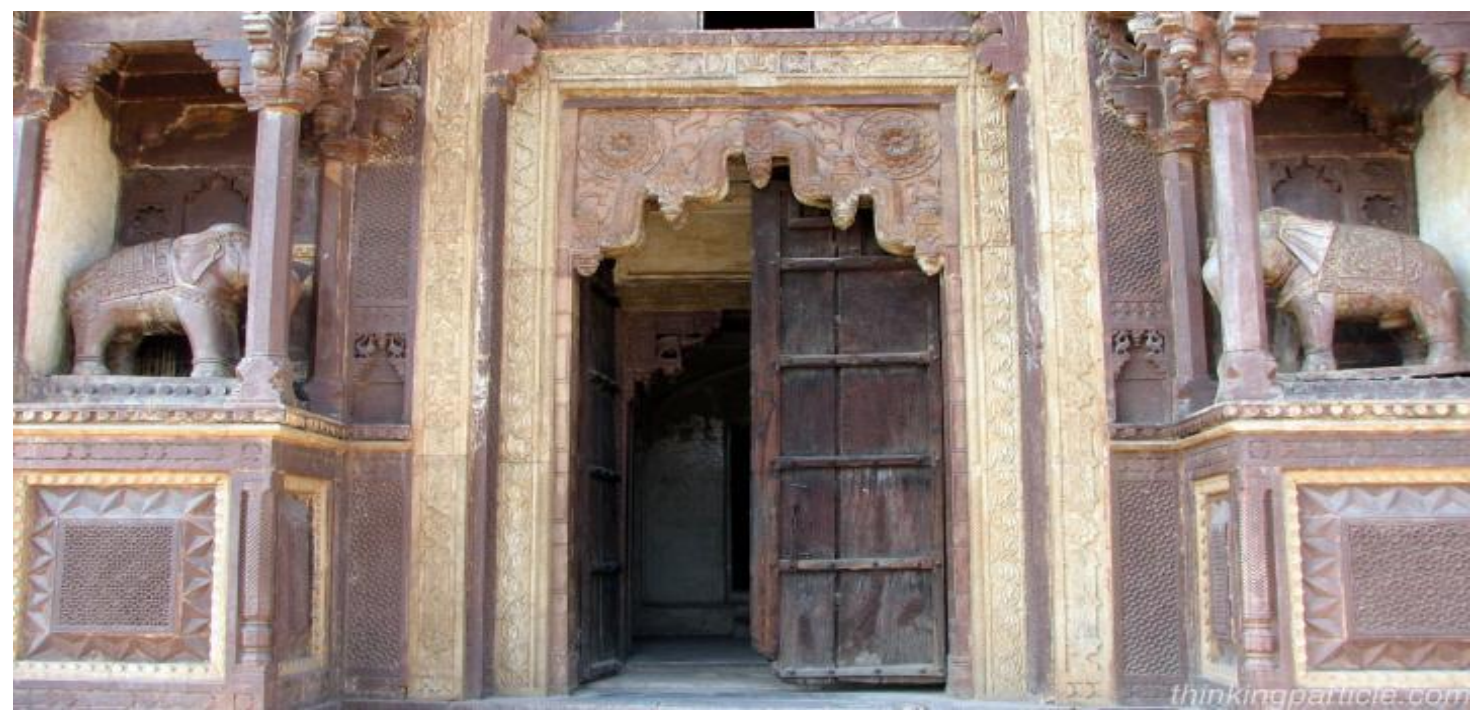

This magnificent Palace has a square shaped courtyard each side has $38 \times 38 \mathrm{~m}$. All four sides have doors of ornate design with intricate arches. The bracket used to support the eaves. It has flora and fauna designs such as lotus-bud, peacock elephant. A V-shaped hanging balcony is also remarkable for its unique pattern of Rajput architecture. ${ }^{13}$ The East facing wall is decorated with Turquoise tiles. ${ }^{14}$ The Hanging balconies with latticework, delicate trellis, graceful Chhatris, ribbed domes, terraces, marvelous sculptures and several rooms with painted murals represents the architectural brilliance, unique aesthetic approach and Grandeur of Bundela dynasty. ${ }^{15}$ Sheesh Mahal palace is located on the west side of Jahangir Palace. It is a retreat palace of Raja Udait Singh which was built during early eighteenth century. Now it is converted in to a Hotel. There is a camel stable named Unth Khana behind the palace.

Photo: Jahangir palace: Lttice work \&Bracket
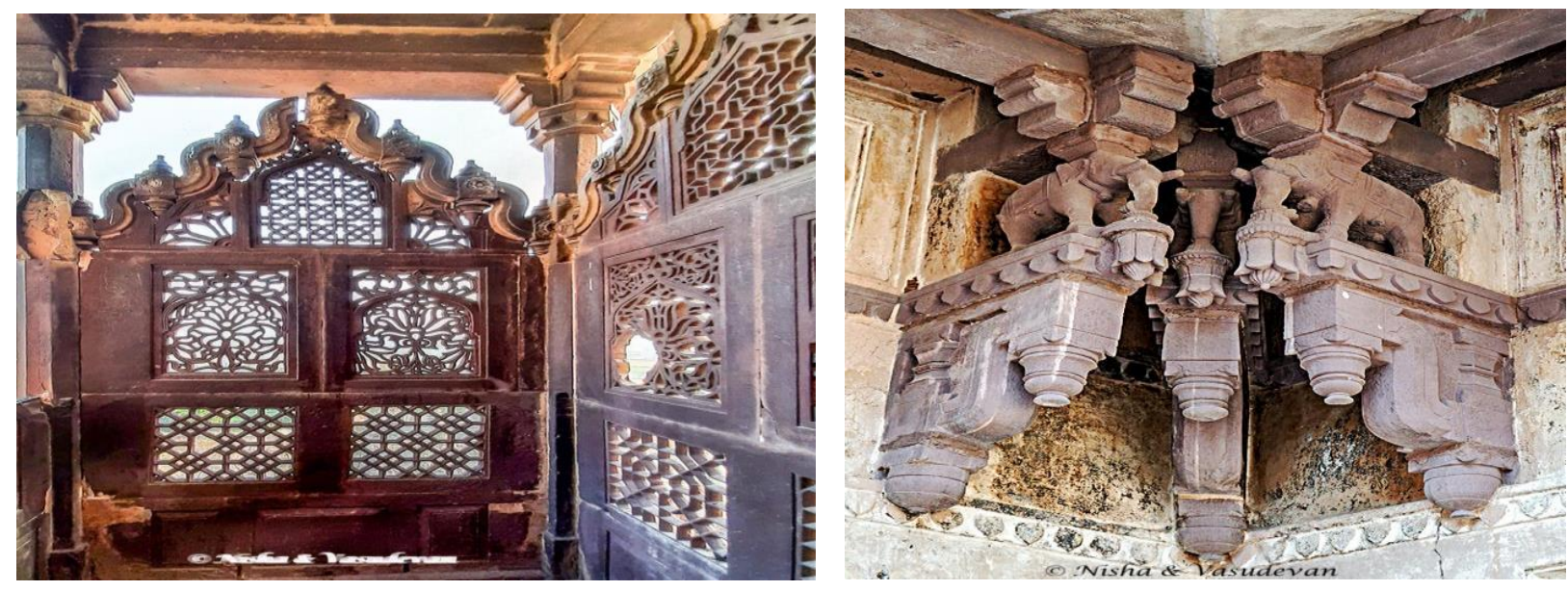


\section{Ramraja Temple:}

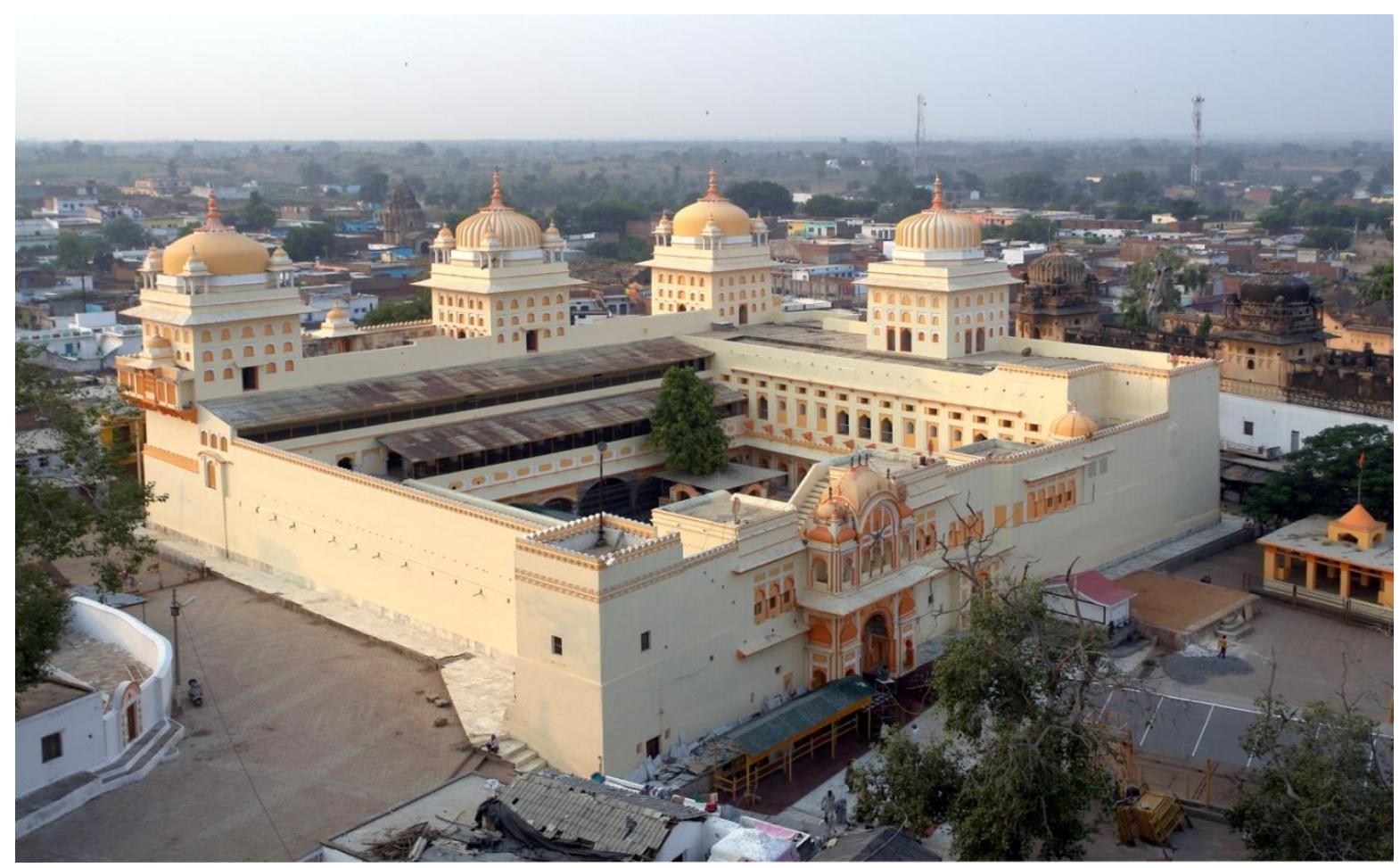

Ram Raja Mandir is the popular pilgrimage of Madhya Pradesh. It is the only place where the Lord Ram is worshipped as a god and as a king. ${ }^{16}$ It is the prominent temple of Orchha situated at the distance of $1 \mathrm{~km}$ from Orchha Fort Complex and 600metres away from Chaturbhuj Temple. In 16th century the temple was built by Raja Madhukar Shah for his queen Rani Ganesh Kunwari as a residential Palace later it converted to the temple of Lord Ram as the idol didn't move from the place as per three conditions: 1st " I will travel with the group of sage on foot from Ayodhya to Orchha only on Pushya nakshatra so Rani traveled to Orchha from Ayodhya with the baby Ram in her lap, it took the time of eight months and twenty seven days to reach the Orchha. 2nd "I will be the king of Orchha and 3rd is, "the first place you will seat to me will be the final place". Thus the Ram became the king of Orchha and King Madhukar Shah shifted her capital to Tikamgarh. In Orchha the Ram is worshipped as a king, so the guard of honour is given every day in the evening by the police personnel of Madhya Pradesh government designated as guard at the temple. The royal feast is also provided to him. In the Garbhagriha of the temple, Raja Ram is sitting in padmasana, with Maharani Sita. He is holding a sword in his right hand and shield in the left. Devi Sita is on his left side while Lakshman ji is on the right, Maharaj Sugriv, Narsingh Bhagwan are also accompanying him. Devi Durga is also present in Ram Darbar. Hanuman Ji and Jamvant ji are praying to them. ${ }^{17}$ 


\section{Photo: Ram Raja Temple}
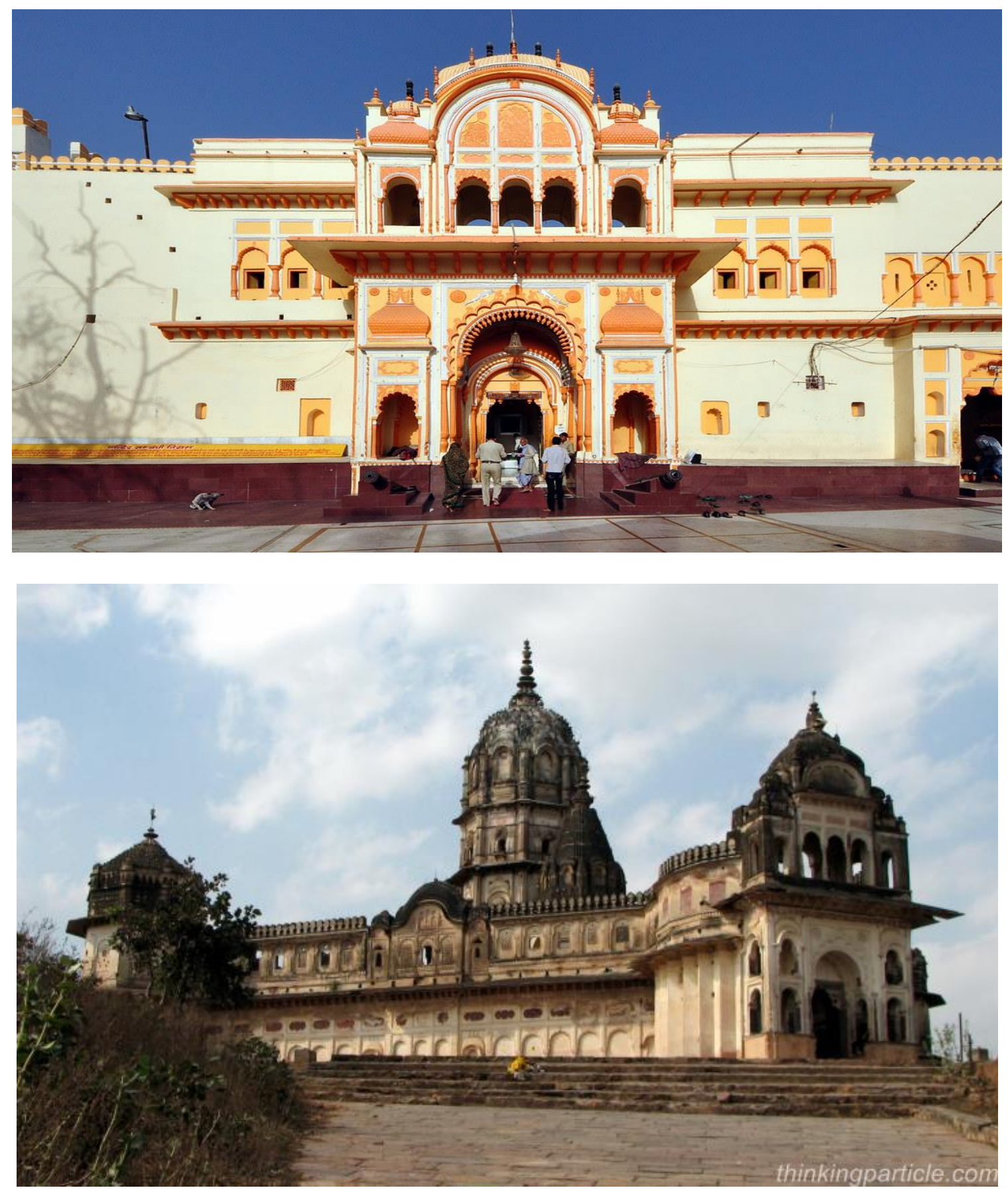

\section{Laxminarayan Temple}

It is one of the famous places which have the unique architecture style dedicated to the Devi the Goddess of wealth. The temple was built by Bir Singh Dev in 1622. Later, it was reconstructed by Prithvi Singh during 1793. 
This temple is 2 kilometres away from the town of Orchha. The walls and the roof of the Temple have the paintings of mythological and historical themes.

Lakshmi Narayan temple has a unique architectural style of amalgamation of fort and the temple 19. The slots for the Cannon which were used at the time of War and bastions projects the fortress appearance. The front view of the temple displays the triangle shape but the structure of the temple is rectangular and has four bastions at the corners. Lime mortar and bricks are used as a material in construction the huge Temple. ${ }^{20}$

The interior of the temple displays the tremendous wall paintings of Orchha style. The themes of the murals are mythological as well as secular. The paintings have marvelous compositions based on the theme of Shri Ramcharitmanas and from the life of Bhagwan Krishna. The historic events such as the battle of Jhansi against Britishers in 1857 has also been exhibited. ${ }^{21}$ Though the temple has been named after goddess Lakshmi but now there is no Idol in the temple after being stolen.

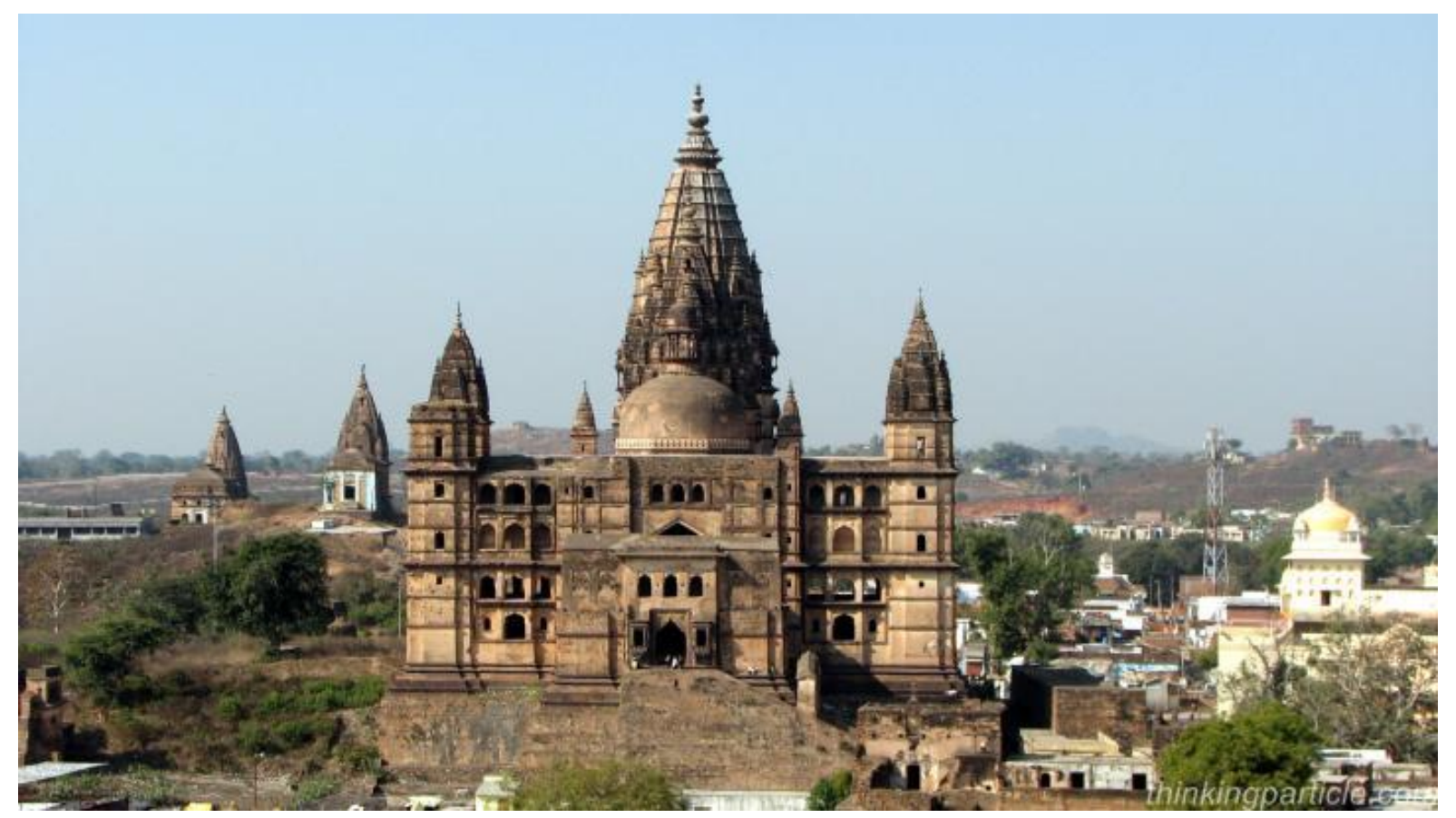

\section{Chaturbhuj Temple}

Chaturbhuj temple is dedicated to Ram, the avatar of Lord Vishnu. It has the literal meaning that 'one who has the four arms' here the 'Chatur' means four and 'Bhuj' means arms.

The temple is situated near Rajaram Temple and $1 \mathrm{~km}$ away from the Orchha Fort Complex. The temple is a multi storey structure with the features of Temple Fort and Palace. This temple has 344 feet Viman which is one of the highest Viman among Hindu temples. The temple was constructed in early 16 century by king Madhukar Shah for his wife Rani Ganesh Kunwari, later it was completed by his son Veer Singh Dev ${ }^{22}$ According to legend Rani Ganesh Gauri was the devotee of Bhagwan Ram. She dreamed that Bhagwan Ram asked her to build the temple for him, so she went to Ayodhya to bring the idol of Ram for her newly constructed Temple. When she came back the temple was under construction, so she kept the Idol in Rani Mahal for the time being. When 
the temple was completed the idol didn't move from the palace so the idol of Lord Vishnu was installed over there that is why it is called the Chaturbhuj Temple, ${ }^{23}$ like Lakshmi Narayan temple the structure of the temple is the harmonious composition of fort Palace and the temple building style with grand and huge entrance Gate.

The temple has pine cones like octagonal Shikhar ${ }^{24}$. The delicate exterior ornamentation and the symbols of religious significance display the unique style of temple architecture.

The other temples are Raghuvanshmani, Radhika Bihari, Panchmukhi and Shiv temple etc are of smaller structure.

\section{Cenotaphs of Orchha:}

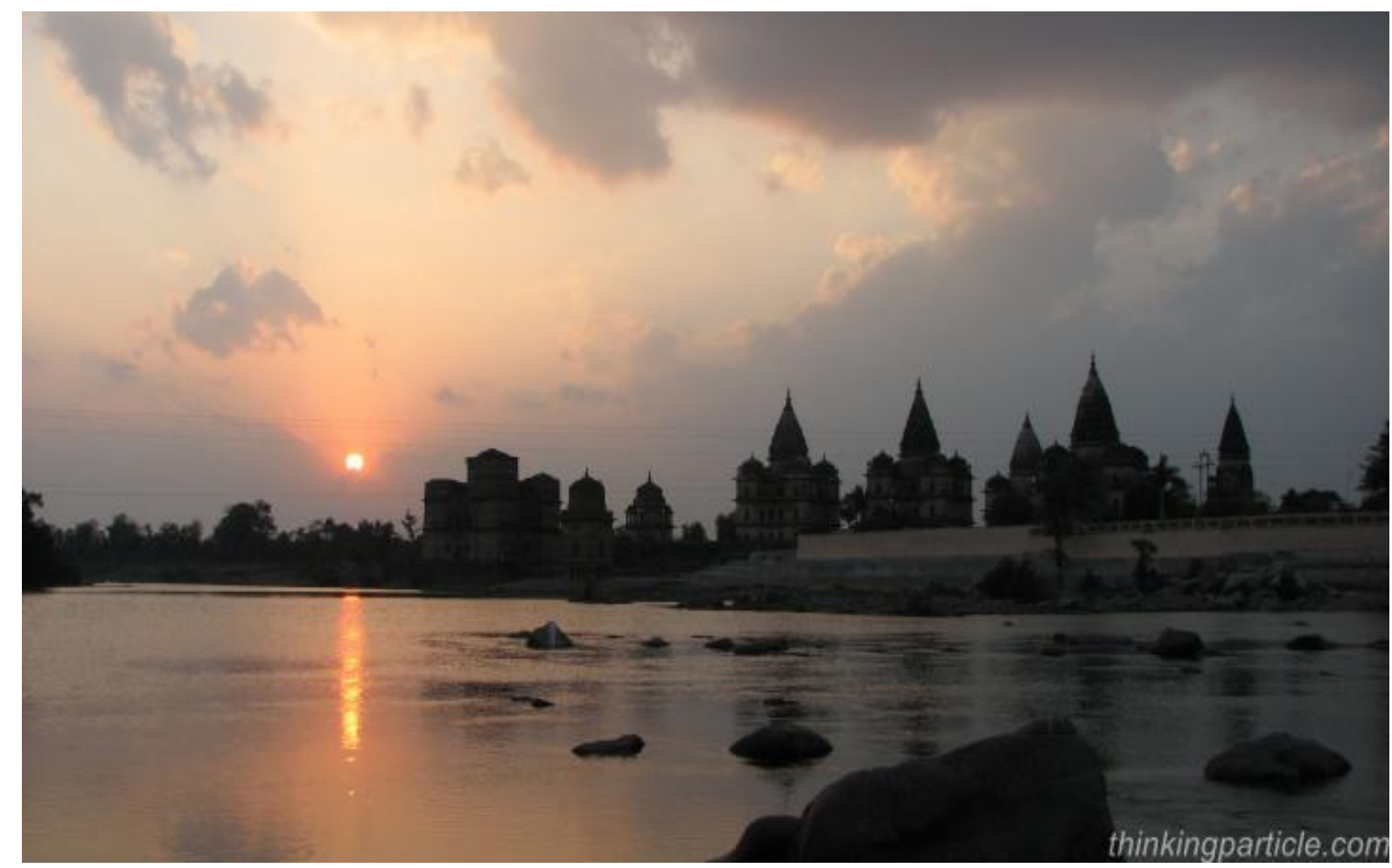

Photo: River side view

Chhatris or memorials of Orchha were constructed in honour of its erstwhile rulers of Bundela dynasty. ${ }^{25}$ At the bank of river Betwa, fourteen stone Cenotaphs are located along the Kanchan Ghat representing the most scenic beauty. These Chatteris are built in memory of the King Bharti Chandra, Madhukar Raja, Sujan Singh Shah, Veer Singh Dev, Jaswant Singh, Maharaja Sawant Singh, Maharaja Bhagwan Singh, Maharaja Indramani Singh, Pahad Singh and others. The cenotaphs are constructed on the uplifted square platform. Most of them are designed in panchayatan style. Chhatri of Maharaja Sujan Singh of Bundela architecture is at the most developed stage. It is a three-story rectangular building of Nagar style, each corner has a square room with topped dome. The central chamber has three arched doors and Nagar style Shikhar of temple architecture. The windows are placed to make it airy. The Cenotaph of Veer Singh Dev has Islamic features like large domes and strong pillars. Its stairway goes to the top. It offers the 
mesmerizing panoramic view of Orchha and its surroundings, ${ }^{26}$ moreover they provide beautiful view with their reflection in the water from the river side

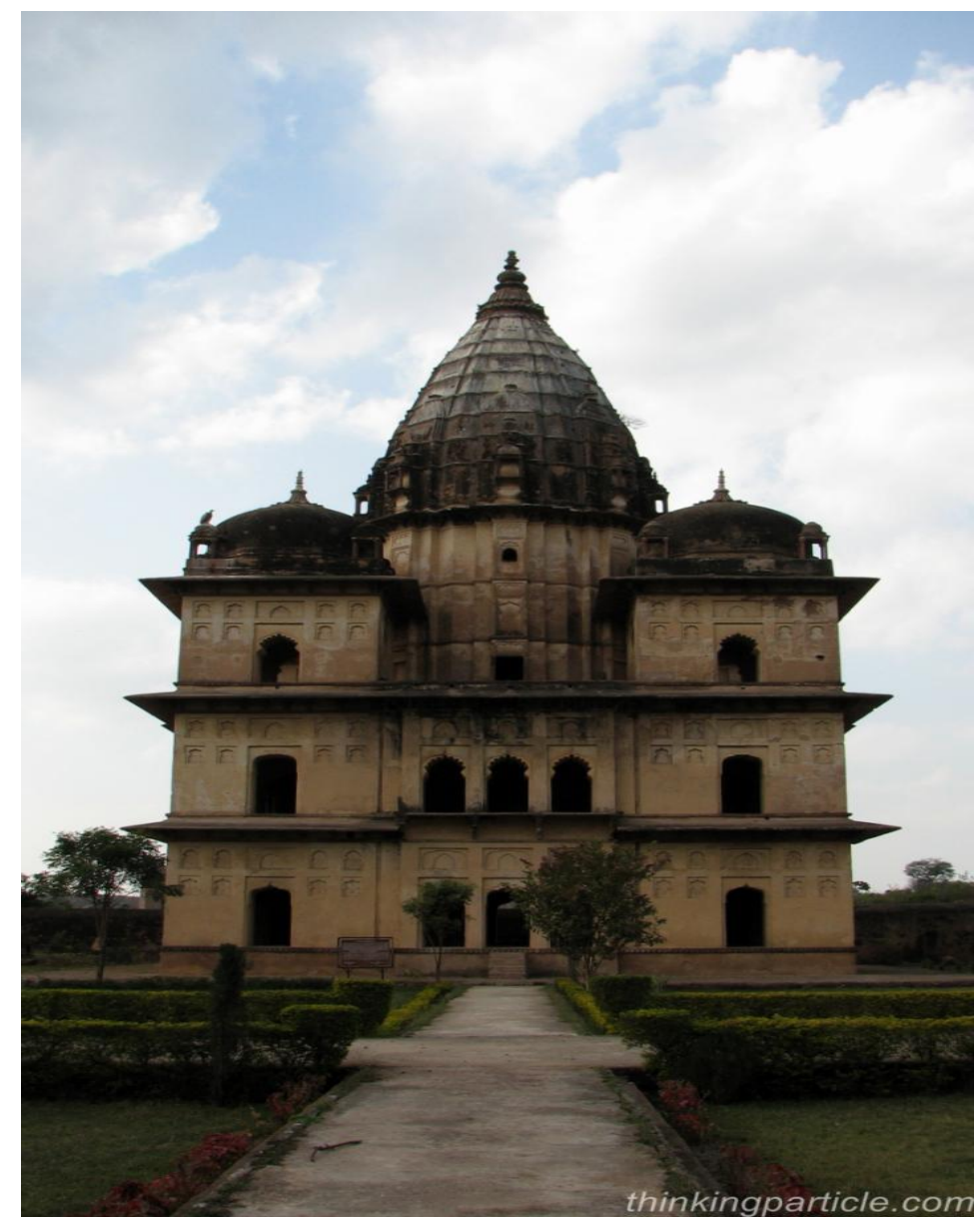

Photo: Chhatri of Maharaja Sujan SinghPhool Bagh:

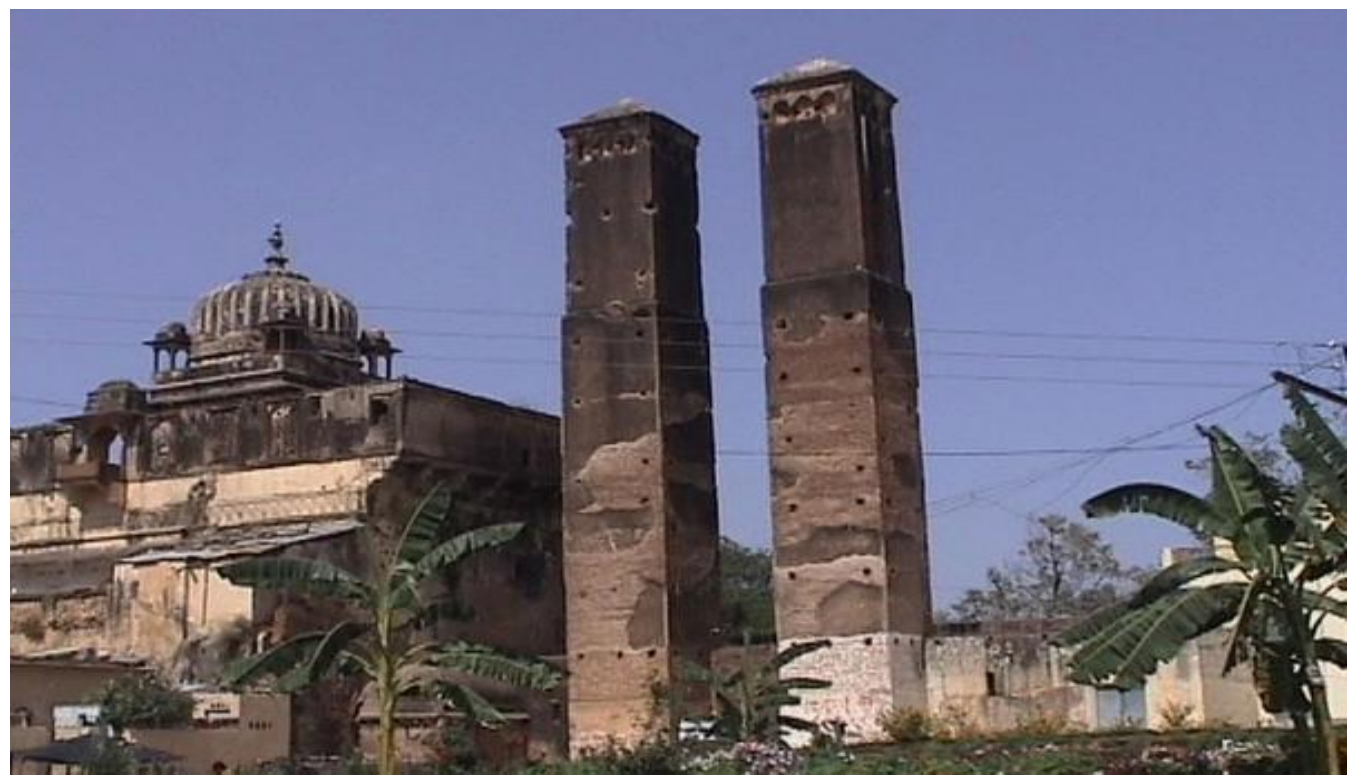


Phool Bagh is situated in the centre of the town, beside the Palki Mahal. ${ }^{27}$ It is also known as Hardaul Vatika which was built in memory of Diwan Hardaul, who died to prove his innocence to his elder brother. The high walled garden is full of greenery that makes the scenario very pleasant. It was used as a summer retreat by kings of Orchha, which presents the high aesthetic perception of Bundela rulers. The architectural plan of phool bagh reveals that it is a Courtyard Garden with the pavements and a pavilion in the centre. The pathways in the garden are elevated with the breadth of 4 meters and wide water channels measuring 1.9 meters in breadth are running down from the centre. It becomes inexplicable when pipes, situated below the floor of the pavilion, bring the water which is stored in a huge container which is stored at the south east of the main pavilion in an inconspicuous place. The moment the water enters in the environment of the garden the view becomes exhilarating. The garden is divided into square quadrants in Charbagh pattern style. Each quadrant has a rectangular grid of eight octagonal of approximately 4.5 meters. The Shrine occupies the center of the garden on an elevated platform; it has taken the place of the 9th grid. The water channel is running down from the underground water tunnel system. The garden has a row of fountains which end in a pavilion. Beneath the garden there is an underground structure which was used as a summer retreat. ${ }^{28}$ The twin towers named Sawan and Bhadon are wind catching towers, they were built for the cooling purpose through the topped ventilator, while its lower part is associated with the water reservoir. They are connected with the Chandan Katora fountain. ${ }^{29}$

\section{Rai Praveen Mahal:}

Rai Praveen was the poet and court musician of Orchha. She was known as the nightingale of Orchha. Kavi Keshav das has composed Kavi Priya in honour of Rai Praveen. Rai Praveen Mahal is a three storied building built by king Indramani for his consort. The hall of the second storey has paintings depicting the various moods of the royal dancer. ${ }^{30}$

The citadel also has the several kothis and other buildings, Dauji ki kothi, Purushottam das ki kothi, Timrat ki kothi are some of them.

\section{Conclusion}

Orchha has an inseparable bond with its cultural heritage, landscape, forest, riverfront, garden, monuments, temples and social and religious fabric. Monuments of Orchha represent the essence of the Bundela period. The Palace Complex has an introverted Courtyard type of architectural plan with some innovative changes. The amalgamation of Rajput and Mughal style mark the achievements of architectural harmony. The temple architecture also appears in a new ingenious design plan. The Fort like structure, octagonal dome, and large open interior projects the interesting gesture. Chhatris are the Memorial of Royale built in panchayatan style of temple architecture, magnificently rest the bank of river Betwa. Gardens are the composition of Mughal Charbagh style and Rajput Fort garden with sacred shrine present the structured strategy for water usage. The Bundela School of paintings portrays the true Bundeli culture of medieval period, the lively court scene and the daily life of the royals and the citizen in walls and ceiling of palace and temples.

The study of Art and architecture explains the fascinating monumental and religious panorama. It also represents and narrates the technique, technology and the overall continuing commitment of 
entire society and ethical-moral fabric which inspires and plays an important role to transmits it from generations to generations.

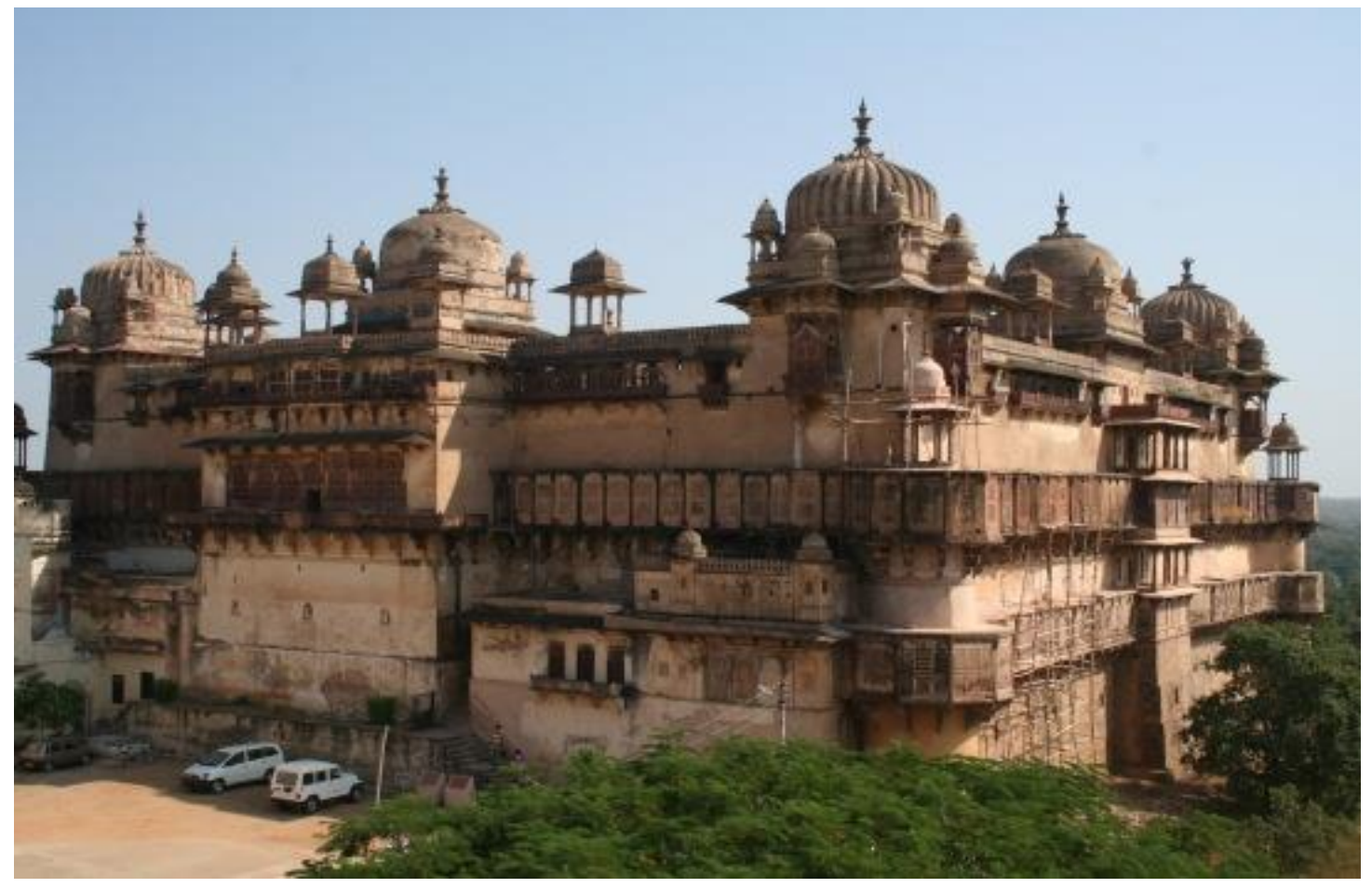

\section{References}

[1] https://whc.unsco.org/en/tentativelists/6404; Orchha, Treval Guide edi by Swati Mitra; An Eicher Goodearth Publication Pvt. Ltd. New Delhi 2009 Pg 7

[2] https://www.drishtiias.com/daily-updates/daily-news-analysis/architectural-heritage-of-orchha

[3] https://www.drishtiias.com/daily-updates/daily-news-analysis/architectural-heritage-of-orchha

[4] A Panorama of Indian Culture: Professor A. Sreedhar Menon Felicitation Volume, edi by K. K. Kusuman, Mittal Publication, pg 157 https://en.wikipedia.org/wiki/Keshavdas

[5] https://issuu.com>orcha_report Cultural Landscape of Orchha; Reclaiming the lost heritage by Amita Sinha; https://whc.unesco.org/en/tentativelists/6404/

[6] https://issuu.com>orcha_report Cultural Landscape of Orchha; Reclaiming the lost heritage by Amita Sinha; https://whc.unesco.org/en/tentativelists/6404/

[7] https://thinkingparticle.com

[8] https://thinking particle.com

[9] https://samanyagyan.com/famous

[10] Orchha, Treval Guide edi by Swati Mitra; An Eicher Goodearth Publication Pvt. Ltd. New Delhi 2009 Pg 16-17; https://thinkingparticle.com/article

[11] https://bundelkhand.in/jahangir-mahal-orchha Orchha, Travel Guide edi by Swati Mitra Goodearth Publication Pg 16

[12] https://roar.media/hindi/main/history

[13] Orchha, Travel Guide edi by Swati Mitra Goodearth Publication Pg 19

[14] https://orchaa.wordpress.com/orchaa-tales/

[15] https://bundelkhand.in/jahangir-mahal-orchha

[16] https://mptourism.com/tourist-place Majestic Orchha

[17] https://en.wikipedia.org/wiki/Ram_Raja_Temple 
[18] https://www.trawel.in/madhya-pradesh>orchha

[19] https://mptourism.com/tourist-place Majestic Orchha

[20] https://www.trawell.in

[21] https://www.trawell.in

[22] https://en.wikipedia.org/wiki/Chaturbhuj_Temple_(Orchha)

[23] https://www.travel.in

[24] https://issuu.com>orcha_report Cultural Landscape of Orchha; Reclaiming the lost heritage by Amita Sinha

[25] https://mptourism.com/tourist-place Majestic Orchha

[26] Culture trip; https://timesofindia.indiatimes.com

[27] lonely planet.com

[28] https://issuu.com>orcha_report Cultural Landscape of Orchha; Reclaiming the lost heritage by Amita Sinha; https://books.google.co.in /Kalyani Majumdar: The Peepal, The Girl and The City

[29] https://orchha.wordpress.com

[30] https://thinkingparticle.com

\section{Photographs Source}

[1] https://breathedreamgo.com/namaste-orchha-hidden-gem-india/

[2] http://www.mptourism.com/tourist-places/orchha-tourism.html

[3] http://www.thinkingparticle.com/image/paintings-raja-mahal-orchha

[4] https://www.travelneedshelp.com/tours/light-and-sound-show-at-orchha-fort-82524

[5] http://www.thinkingparticle.com/image/roof-jahangir-mahal-orchha

[6] https://www.lemonicks.com/asia/india/madhya-pradesh/orchha/exploring-orchha-fort-complexmadhya-pradesh/

[7] https://www.lemonicks.com/asia/india/madhya-pradesh/orchha/exploring-orchha-fort-complexmadhya-pradesh/

[8] http://www.thinkingparticle.com/image/entrance-jahangir-mahal-orchha

[9] https://en.wikivoyage.org/wiki/Orchha Ramraja temple

[10] https://www.flickr.com/photos/asienman/11271164533/ Ramraja temple

[11] http://www.thinkingparticle.com/image/lakshmi-temple-orchha

[12] http://www.thinkingparticle.com/image/chaturbhuj-temple-raja-mahal

[13] http://www.thinkingparticle.com/image/sunset-orchha

[14] http://www.thinkingparticle.com/image/cenotaph-maharaja-sujan-singh-orchha

[15] https://orchaa.files.wordpress.com/2012/06/twin-towers.jpg

[16] https://www.drishtiias.com/images/uploads/1567664744_image1.jpg

*Cor responding author.

E-mail address: anjali_pandey11@yahoo.com 